\title{
Greater than the sum of its
}

\section{parts: the growing impact of}

devolution on the processes of constitutional reform in the United Kingdom

by Chris Himsworth

This article is the revised text of a lecture given at the Institute of Advanced Legal Studies on December 8, 2008, under the chairmanship of Lord Hope of Craighead and as the first in a series on "What's Happening in Scotland?".

$\mathrm{W}$

hen I was first invited to talk, in London, about "What's happening in Scotland", I'm afraid my mind turned to that scene towards the end of Macbeth set in England, "Before the King's Palace". Shortly, Ross arrives and poor Macduff asks: "Stands Scotland where it did?" And Ross has to reply: "Alas, poor country!" And then adds a tale full of sighs and groans and shrieks. I may have the occasional sigh or groan or even shriek but, happily, I was also reminded of the comment of the Lord President of the Court of Session on March 11, 2008 in evidence to the Justice Committee of the Scottish Parliament. He said: "We live in pleasant times." That is to quote him out of context. He was explaining to the Justice Committee that, in these pleasant times, a formal guarantee of judicial independence might not be required. He was acknowledging, however, that times might not always be pleasant and that, in those circumstances a statutory guarantee might then be important.

For some, these are pleasant times. I think, in particular, of the Scottish First Minister Alex Salmond and his ministers, the Government of Scotland since May 2007. Admittedly, Glenrothes last month reduced the pleasantness of Glasgow East in July 2008. Despite Glenrothes, things have been distinctly less pleasant and much harder work for Prime Minister Gordon Brown.

My task tonight is to focus on public law rather than politics, although I shall have to say a little in a minute about the impact of current political developments on governance under devolution. What I want to do is to extract from these developments a selective account of the impact of the ten years of devolution on the development of constitutional law and public law in general in the United Kingdom as a whole.

My argument will be, as indicated by the rather clichéd "sum of its parts" of the title of my lecture, that the devolution of power to the Scottish Parliament and the Scottish Executive since 1998/99 - quite unlike, for instance, the 50 years of Stormont Government in Northern Ireland - has had an important impact on the general UK reform agenda. I am not for a minute saying that Northern Ireland and Ireland itself in the period 1922-72 had no effect on UK politics and government. Of course they did - but in ways which, for the most part, were confined to the resolution of the Northern Ireland question itself - whether separately or whether, as with the report of the Kilbrandon Royal Commission on the Constitution in 1973, in a wider UK context.

I think the impact of Scottish devolution has been different. With a particular focus on the UK Bill of Rights debate and the question of the UK Supreme Court, I want to suggest that the particular conditions of devolution in Scotland - accentuated but not wholly dependent upon the results of the Scottish Parliament elections of 2007 - are having a limiting, if not at times a paralysing, effect on constitutional debate. It is the particular mix of constitutional, legal and political conditions which creates the difficulty. It does, of course, remain the case that, in a formal sense, the UK Parliament (subject to the qualifications expressed by their Lordships in $R$ (Jackson) $v$ Attorney General [2006] 1 AC 262) remains supreme. In a 
less formal sense, there may still be some lingering truth in the claim that "power devolved is power retained". But for most practical purposes we have to acknowledge that devolution has delivered a new constitutional environment which places constraints (which may or may not be a good thing) on the central government and Parliament. This may seem obvious but it is not, I think, fully appreciated. There are a number of factors.

There are, first, the powers formally devolved. Coupled with the obligations which flow from the Sewel convention, these effectively leave many areas of constitutional activity beyond the reach of the UK Government and Parliament acting alone. They also create the tricky areas where the boundaries of reserved and devolved power are less than clear, where, for instance, reserved immigration powers overlap with devolved areas of social provision. And the example recently highlighted in the UK Government's submission to the Calman Commission on Scottish Devolution where reserved powers of energy (including nuclear) provision overlap with devolved powers of land use and development control. It is apparent that UK ministers find some of these overlaps irksome and seek readjustments in a revision of the Scotland Act settlement.

I'll mention later some overlaps affecting the administration of justice in Scotland. Consequences of a particularly interesting kind for lawyers arise in the delivery of reserved services through a substantially devolved legal system.

Then, secondly, there is a close connection between the powers constitutionally devolved and the resulting politics of devolution. In the first place, there is no rowing back. There are too many beneficiaries of devolution - right across the political party spectrum - to contemplate a substantial redistribution of powers back to the centre (although there may be some tweaking in that direction, as sought by the UK Government in relation to certain functions).

Just as important, however, for present purposes is the emerging consensus that (a) the devolutionary status quo is not sustainable in the longer term but equally that (b) there is a lack of agreement as to what might be done. The unsustainability derives not from the fearful asymmetry itself of the current devolution arrangements across the UK but particular manifestations of that asymmetry in the shape of problems of, first, political representation especially in the shape of the West Lothian question; secondly, resentments, on all sides, of the current model for the distribution of financial resources - the Barnett formula and all that; thirdly, resentments (I gather) in England about not just extra funding in Scotland but also its benefits in terms of free personal care for the elderly, free university education, and free medical prescriptions on the way. And, finally, in a situation exaggerated but not invented by the election of the new Scottish Government in 2007, there are insufficient means for the formal anticipation and resolution of potential disputes between governments.

On the one side of the debate about ways forward, the solution is seen in terms of weakening of the Union in the direction of independence - but with increasingly sophisticated versions of what independence within Europe and in association with neighbouring states might mean. (As a tiny example, I was interested to hear the other day of SNP proposals to continue to use Swansea for vehicle licensing after independence.) On the other side, those whose constitutional policy futures assume the continuity of the Union have lost sight of a credible vision of a future Union. Hence the paralysis. There is no consensus as to what even the minimum requirements of Union are; in particular, what shared rights of citizens across the UK there ought to be.

As an aside, there is not even a consensus as to what governments call each other nowadays. It may have been lost on many of the overseas guests but it was instructive to witness the conflict at the opening of the Commonwealth Law Ministers conference in Edinburgh in July of this year in the firm references of the Deputy First Minister to her "Scottish Government" but the Attorney General Baroness Scotland's equally deliberate references throughout her address to her government's co-operation with the "Scottish Executive".

The result is that constitutional reform at the UK level has to take its place, along with other policy debate in this highly contested zone. Symptomatic of the contest is the current turf war between the SNP Government's National Conversation about Scotland's constitutional future and, on the other hand, the Calman Commission established by resolution of the Scottish Parliament and with the support of the UK Government.

The relationship between the two visions of the future can be expected to be in flux for some time. It is suggested by some that the SNP goal of a referendum in 2010 may be undermined by the political fallout from the current financial crisis. Meanwhile the Calman Commission has issued its interim report. I do not want to discuss its contents in detail here. It does, in any event, leave most significant questions for further consultation and consideration. Perhaps, though, its principal significance lies in its robust defence of devolution so far and the beginning of an exploration of the basis on which the future of the Union may be best analysed.

My emphasis is to be on problems but before turning to the more problematic areas, in the interests of balance and trying to respect an obligation to be more comprehensive in my public law coverage of "what's happening in Scotland", I should mention some developments (in recent years) which have been more straightforward. Some impacts of devolution have been constraining but other developments have been enabled or at least permitted by 
devolution and they fall into two categories. They are either in the areas of devolved legislative competence where the Scottish Parliament has legislated or is proposing to do so; or they are developments done at the hand of the courts not (necessarily) as a consequence of devolution, but during the era of devolution.

In the first category, I would mention two examples - the first being the recently enacted Judiciary and Courts (Scotland) Act 2008. It is an Act which has a long prehistory. Proposals for a Bill reached an advanced stage under the Labour/Liberal Democrat coalition and were carried forward, since May 2007, by the SNP Government. It was a Bill which drew quite heavily on the model of the UK Constitutional Reform Act 2005 but with its own distinctive characteristics. Now the new Act provides a statutory guarantee of judicial independence; it formally establishes the Lord President of the Court of Session as the Head of the Scottish Judiciary; it puts the Judicial Appointments Board on a statutory footing and enacts new rules of judicial conduct and dismissals. It reestablishes the Scottish Court Service, headed by the Lord President, as a non-ministerial office within the Scottish Administration.

Where it deals with tribunals to consider the dismissal of judges, the Act completes a piece of unfinished business under the Scotland Act by replacing rules initially made by UK ministers in 1999 under that Act.

Other rules of that sort which have taken a long time to replace are those which laid down procedures for the making of statutory instruments (in the Scottish Parliament) - essential from the launch of devolution in 1999. Broadly, the code of the Statutory Instruments Act 1946 was adopted for Scottish SIs. The development of a new code of Scottish-built rules has been in the hands of the Subordinate Legislation Committee of the Scottish Parliament as the principal component of their Regulatory Framework Inquiry. In Session 2 of the Parliament, the committee produced some very radical proposals. These would, in particular, have required drafts of virtually all SSIs to be laid before the Parliament. More recently in the 3rd Session, the reconstituted committee has produced some much less adventurous proposals and the Scottish Government is to adopt these in a Legislative Reform Bill in the coming months.

A government without a majority in the Parliament is disabled from engaging in politically controversial legislative initiatives but progress can be made in areas such as those I have mentioned - which are uncontroversial between the main parties.

Turning to my, equally highly selective, review of developments in the courts, I'll be dealing with some human rights issues in a minute. But I would first like to mention one or two others whose scope is nicely encapsulated, if I may say so, Chairman, in two extracts from the speech of Lord Hope of Craighead in Davidson $v$
Scottish Ministers (No 1) $2006 \mathrm{SC}(\mathrm{HL}) 41$. One is where he said: "There are occasions when those of your Lordships who come from Scotland feel justified in defending Scots law and the Scottish legal system against what are perceived to be alien influences. But this" he said, "is not one of them" (para 38). Davidson was the case in which the House of Lords, the Scottish judges in particular, brought the Scottish and English jurisdictions into alignment (but without crude assimilation) on the matter of interdicts against the Crown in judicial review. Whilst some other areas of judicial review have remained defiantly different including the very scope of that jurisdiction, as defined in West v Secretary of State for Scotland 1992 SC 385, there have been other instances of considered realignment. Porter v Magill [2002] 2 AC 357 was the case in which Lord Hope resolved earlier divergences on the test for bias or apparent bias and $R$ (Burkett) v Hammersmith and Fulham LBC [2002] 3 All ER 97 the case in which he sought out the similarities of approach in principle to questions of delay in initiating judicial review proceedings. Extra judicially he has declared his frustration with the relatively restrictive approach to locus standi in judicial review in Scotland and sought a convergence between the two jurisdictions in that area as well ("Mike Tyson comes to Glasgow - A Question of Standing" [2001] PL 294).

It was also in Davidson that Lord Hope took the opportunity to observe that judges in the House of Lords had, he said, "the benefit of examining the issue in a tribunal which draws its membership from all parts of the United Kingdom.... There is everything to be gained," he said, "by the sharing of views among your Lordships which it has been possible to enjoy in this case"(para 38). This is to anticipate the stance which we may expect to be adopted in the new UK Supreme Court from the autumn of 2009 - an openness, at least in matters of public law, to the testing of whether rules should or should not have a UKwide application.

It would be possible to add footnotes, at this point, in which might lurk additional references to such things as Tehrani $v$ Home Secretary 2007 SC(HL) 1 on the IPL consequences of judicial review; cases which have confirmed the application of the Carltona principle to acts of the Scottish Ministers; and another potentially rich area for development is that of the consequences (post devolution) of the divisibility of the Crown. This has been explored recently in great detail in the light of $R$ (on the application of Quark Fishing Ltd) v Foreign Secretary [2006] 1 AC 529 by Anne Twomey (see "Responsible Government and the Divisibility of the Crown" [2008] PL 742). Amongst other things, she discusses the role of the Privy Council and Privy Counsellors in the making of Orders in Council - another of those areas in which the complexity of the devolution arrangements is exposed as UK ministers tender "advice" on matters within the devolved competence of the Scottish Government. 


\section{HUMAN RIGHTS}

I now want to move on to two of the more contested areas of constitutional development and to start by saying a few words about devolution-related aspects of the UK Government's UK or British Bill of Rights project. I am not completely sure where that project is headed just at present. Things seem to have gone very quiet. There was an expectation in the summer that a new White Paper was imminent but there has been no further public sign of this - except perhaps in reactions to the sudden resignation of Lord Lester as a government advisor on human rights in November 2008.

There have, of course, been many other pressing things on the minds of ministers. But the proposal for a new Bill of Rights (and probably duties or responsibilities) has been a project at the centre of the Brown package of constitutional reforms and it was, it seemed, also at the centre of the wider "Britishness" project. And one might have thought that the Britishness theme was one which would have rung some devolution-sensitive bells in Whitehall. But there was, in fact, no discussion of devolution-related aspects of human rights in the reform Green Paper of July 2007.

In part, this may be simply an example of a failure to take account of an obvious point of political sensitivity. And, as an aside, one might note that this is not confined to human rights matters. In An Elected Second Chamber: Further Reform of the House of Lords Cm 7438, (July 2008) there is a reference to the possible future role of religious leaders in a reformed House. The document (prepared by a Ministry of Justice into which the Scotland Office is said to be integrated as a "distinct entity") referred to the presence of Bishops in the House of Lords as signalling the commitment of successive governments to "an expression of the relationship between the Crown, Parliament and the Church that underpins the fabric of our nation!" (para 6.45 - exclamation mark added!) (Mind you, devolutionary sensitivities can crop up in odd places. I am currently in discussion with a large law publisher about my insistence on a lower case "s" for schedules to Acts of the Scottish Parliament!)

There was some treatment of the impact of devolution on any new UK Bill of Rights in the report of the Joint Committee on Human Rights which was published in August 2008. My own, rather unhelpful, two-line submission to the committee had raised questions about the viability of the project, given the probable need for a Sewel Motion.

I want to return to the Joint Committee report, but first I should say a few words on Scotland's experience of (post 1998) human rights law developments so far. It has been a bit of a bumpy ride - in ways which would not have been predicted in 1998 when it seemed to be assumed that the Human Rights Act regime had been quite carefully enmeshed with that of the Scotland Act to produce an integrated code. I would pick out four aspects.
1. In the first place the engagement of the Scottish Parliament and Executive with human rights limitations from their start-up in 1999 (and thus well in advance of the general HRA commencement date of 2 October 2000) brought the unexpected exposure of the Scottish criminal courts to human rights challenges, resulting from the involvement of the Lord Advocate - a member of the Scottish Executive - as prosecutor and with the particularly intrusive decision in Starrs v Ruxton 2000 JC 208 that temporary sheriffs were unacceptable and had to be abolished.

2. A second high-profile consequence of an unexpected interaction between the Human Rights Act and the Scotland Act was the divergence which emerged between the Judicial Committee of the Privy Council in the case of $R_{V} H M A 2003$ SC(PC) 21 and the Appellate Committee of the House of Lords in AG's Reference No 2 of 2001 [2004] 2 AC 72 on the question of the impact of Convention rights on prosecutorial delay in criminal trials - a divergence which was, however, later resolved in Spiers v Ruddy 2008 SLT 39.

3. Another occasion for a sharp divergence - this time between the Inner House of the Court of Session and the House of Lords - came in Somerville $v$ Scottish Ministers 2008 SC(HL) 45 where a particularly strong difference of opinion arose over whether the 12-month time ban on proceedings under the HRA should also apply to proceedings brought as a devolution issue against the Scottish Executive under the Scotland Act. And the result has been, through the decision of the House of Lords in the case, that it does not. Somerville brought conflicting interpretations of the two Acts too complex to explore fully here but which, put crudely, forced a choice between the logic of similarity of treatment under the two human rights codes - which had attracted the Inner House to a 12-month rule common to both - and, on the other hand, the logic of treating the human rights challenge as one of several which might be brought as competence issues under the Scotland Act where, quite plainly, no general 12 month rule applied - the view which, on its interpretation of that Act, attracted a majority in the House of Lords (for discussion see C Himsworth, "Conflicting Interpretations of a Relationship: Damages for Human Rights Breaches” 2008 (12) Ed LR 321).

4. I should mention one quite separate human rights development with a devolutionary twist to it. There has, I think, been no opportunity for a Scottish court to engage with the question of what constitutes a "public authority" - a "person certain of whose functions are functions of a public nature" - for the purposes of section 6 (3) of the HRA. But, in the light of $L_{V}$ Birmingham City Council [2008] 1AC 95 the opportunity was taken in section 145 of the Westminster Health and Social Care Act 2008 to amend not only the 
England and Wales statute but also the Social Work (Scotland) Act 1968 to ensure that private providers become subject to the HRA. Those who keep an eye on these things will have noted that, although the Health and Social Care Bill was the subject of a legislative consent motion in the Scottish Parliament, the clause which became section 145 was not - perhaps because it was simply a late amendment to the Bill, but perhaps because it was thought not to be within the competence of the Parliament.

I mention these human rights developments mainly to remind that the quest for compliance with Convention rights has brought some quite difficult consequences many of them unforeseen - for the working of the human rights settlement so far. To talk now of whether and, if so, how to superimpose a new form of UK or British Bill of Rights revives these questions of compatibility between the human rights and devolution regimes. Some of these questions are narrow and technical. Some of them are broader questions about the legislative competence of the Scottish Parliament.

Let me try to illustrate the difficulties which arise by reference to the Joint Committee report I have already mentioned. The committee came to Edinburgh and took evidence from the Scottish Government's Cabinet Secretary for Justice, Mr Kenny MacAskill, and representatives of the Law Society of Scotland. The committee also took evidence on Northern Ireland where arguably the problems involved in talking about a new and explicitly British or UK Bill of Rights which could disrupt the delicate understandings underpinning the Belfast Agreement of 1998 might loom much larger than anything thrown up by Scotland.

I have two principal comments on the committee's response to their encounters with evidence from Scotland and Northern Ireland. The first is to note the committee's correct insistence on the need for communication between the UK Government and the devolved administrations. Kenny MacAskill had been asked about the extent to which the Scottish Government had been involved in discussions on a Bill of Rights. He said:

$$
\begin{aligned}
& \text { "Not really a great deal at all and I think the fact that } \\
& \text { devolution is not mentioned is perhaps an indicator of that". }
\end{aligned}
$$

The UK Justice Secretary had accepted in evidence that the government had, he said, "to ensure that what we say does not collide with the devolution settlement and, if there is a question of that, it has the consent of the devolved administrations". The committee agreed: "A UK Bill of Rights must be based on a detailed dialogue between central government and the devolved administrations. We note that this dialogue does not yet seem to have begun" (paras 103-04).

And later the committee repeated the need for "early engagement" with the devolved administrations. This was, in part, in response to the UK Justice Secretary's view that there were "tricky" drafting questions rather than matters of principle arising from the devolution settlement.

My own second comment on the committee's report, however, is to doubt whether it is simply drafting questions which are involved. The committee's own broad conclusion on the dimensions of the devolution-related problems was as follows:

"The devolution settlement creates certain difficulties for a UK Bill of Rights, but we do not accept that it creates an insuperable obstacle to such a Bill. Ever since the Universal Declaration of Human Rights, human rights norms have gradually become embedded at global, regional and national level. Provided the hierarchy between these levels is clear, there is a positive virtue in the broadly defined rights in the international standards being fleshed out into more concrete norms and standards at the regional, national and subnational level. Each Bill of Rights, from the global through the regional to the national and sub-national levels, becomes more specific and detailed in its provisions, and is free to be more generous but must not fall below the minimum floor of the higher level of protection. It is common for federated states, such as Canada, the US and Germany, to have both federal Bills of Rights and state-level Bills of Rights, and for any questions about the hierarchical relationship between these different levels of rights protection to be resolved by the federation's Constitutional Court. In our view," the committee continued, "the devolution settlement creates fewer difficulties than face federated states in this respect, because constitutional matters, including human rights, are not devolved matters" (para 107).

"Nevertheless", they said, "devolution raises complex issues, particularly if a UK Bill of Rights concerned devolved matters" (para 108).

Professor Carol Harlow of the London School of Economics had argued:

"Human rights are not, of course, a devolved issue, a division of functions that perhaps remains largely uncontroversial so long as the matter is governed by the Convention and our shared heritage in that respect. Were this to change and more particularly if a proposed new text were to penetrate deeply into economic and social rights, devolved areas would be involved.... Whether further regionalisation is desirable and what the relationship of regional texts could be with the ECHR and Strasbourg courts are very difficult and delicate questions" (para 121).

The committee went on to say that they had received some helpful evidence from the Law Society of Scotland about the difficulties of a UK Bill of Rights in a Scottish context. Some well known civil rights south of the border, such as the right to trial by jury, were not, they conceded, part of Scotland's constitutional heritage (para 122). In addition, an amendment to the Scotland Act 1998 would be required to ensure that provisions of a UK Bill of Rights 
relating to devolved matters could not be repealed or derogated from by the Scottish Parliament (para123).

In response, I do very much agree about the problems which might arise if newly defined "rights" promulgated at a UK level began to impinge on those areas of social policy currently devolved to the Scottish Parliament - whether or not they are in areas where Scotland's "constitutional heritage" has been different from that of other parts of the United Kingdom. There would, at the very least, be the problem of protecting them from future modification or derogation by the Scottish Parliament. I'll come back to that but there are bigger problems.

The first is the conclusion by both Professor Harlow and the committee that human rights are not devolved matters. The main difficulty here is that, in terms of the Scotland Act, the conclusion is simply not technically correct. For a matter to be "not devolved", it must be reserved and there is no indication in Schedule 5 to the Act that this is the case. Certain "constitutional" matters are reserved but these are contained in a closed list which does not refer to human rights. There is a reservation of "equality"/nondiscrimination rights but this does not extend to human rights in general. When the Scottish Commission for Human Rights was created by the Scottish Parliament care was taken not to impinge on the reserved equality matters just as there had been a sensitivity to the Scottish devolved areas in the creation of the UK Equality Commission. But no one would have challenged the competence of the Scottish Parliament to legislate on human rights in general. It is true that the Human Rights Act 1998 joins other statutes (mainly large parts of the Scotland Act itself) which cannot, by virtue of Schedule 4, be modified by the Scottish Parliament but a Bill in the UK Parliament designed to repeal or amend or replace the Human Rights Act would, I assume, require a legislative consent (Sewel) motion in the Scottish Parliament because of the Bill's encroachment on devolved matters - both in respect of its touching on human rights at all and, if this were the case, its extension into other aspects of devolved legislative competence such as criminal justice or education or housing policy.

Nor is this simply a technical matter of getting a legislative consent motion approved (or not) by the Scottish Parliament. Of course, that is, in any event, a matter of mere convention rather than law. But this is where the line in the Joint Committee's report about an amendment to the Scotland Act being required and the cheerful reference to the devolution settlement's creating "fewer difficulties than face federated states" become problematic. Of course, in a formal sense, the sovereignty of the UK Parliament could in theory be asserted in a way that would not be the case in a federation but, to say this, is to ignore the constitutional realities of the UK to which I have referred.

We have to bear in mind that in Mr MacAskill's evidence to the Joint Committee, he spoke not only of a lack of communication between governments but also of his own general antipathy to the project. In answer to the straight question of whether a UK Bill of Rights was needed, his one-word answer was a simple "no".

On the matter of a UK or British Bill of Rights, I would predict a very difficult future.

\section{SUPREME COURTS}

I move on now to my second principal area of constitutional development selected for treatment, the UK Supreme Court.

But before I discuss the "top court" proper let me go off on another small devolutionary excursion in relation to the Scottish legal system more widely. Two issues come together as aspects of the jurisdictional asymmetry exposed by devolution (see CMG Himsworth, "Devolution and its Jurisdictional Asymmetries” (2007) 70 MLR 31).

One is the general question of tribunal reform in Scotland. The Leggatt review acknowledged the complications caused by devolution and the resulting division of the Scottish system into devolved and non-devolved tribunals. And the Tribunals, Courts and Enforcement Act $2007 \mathrm{did}$ not intervene to reform devolved tribunals. Since then, however, the Administrative Justice Steering Group has reported, with options for the future organisation of tribunals in Scotland including, most ambitiously, a single Scottish Tribunal service embracing both devolved and reserved tribunals - in the same way that the devolved system of courts handles both devolved and reserved matters.

To make that comparison with courts touches on another area of more specific current sensitivity. One change that was made by the Tribunals, Courts and Enforcement Act 2007 and which did affect Scotland was the provision (in ss 20-21) for the transfer of judicial review applications from the Court of Session to the new Upper Tribunal. Now it may be that in England and Wales such a transfer can be treated as a fairly easily accommodated adjustment of the court and tribunal systems. In Scotland, however, there is an inevitable sensitivity about the idea of the transfer of business from being handled within the supervisory jurisdiction of the Court of Session to a new home in a UK tribunal. The misgivings hardly need to be articulated. In terms of section 20 of the 2007 Act such transfers cannot currently include applications to the supervisory jurisdiction which challenge decisions under the Immigration Acts. But in the Border Agency consultation on immigration appeals of August 2008 the proposal is made (as for the English High Court) to remove the immigration case restrictions - whilst stating that the Agency, referring to Lord Gill's review of civil justice, remains open minded as to exactly how judicial reviews will be handled in Scotland". To which one might say: "So they should". But, as the Agency also insists, immigration is not a devolved matter but within their reserved domain. 
And there has already been some quite intrusive intervention into Scottish court practice to accommodate, for instance, the "special representatives" required by the Prevention of Terrorism Act 2005. Whatever the eventual outcome and whatever its rights and wrongs, here have been signs that the Border Agency's consultation has been alarmingly narrow so far.

The problem about how to handle both tribunal reform and the changes being made to judicial review is that there are evident difficulties which arise from the administration of some reserved areas of policy through a legal system which is devolved and, therefore, beyond the direct control of the central government.

Returning specifically to the UK Supreme Court, I want to make a couple of further points.

The first is to remind of the unhappy launch of the constitutional reform project in the aftermath of the Lord Chancellor (abolition of) announcement in June 2003. Suddenly, so suddenly, we gather, that even existing Law Lords were caught unawares, in an associated reform, the Appellate Committee was to be replaced by a new UK Supreme Court. Inevitably great sensitivities were raised and doubts expressed and, as the Constitutional Reform Bill proceeded, one result was that the clause protective of the separateness of the UK jurisdictions was incorporated. It was certainly not the right climate for the serious consideration of whether, for instance, there might be greater uniformity of appellate jurisdictions across the UK. The apparent oddity in the supreme court of a state in its having a shared civil jurisdiction but an asymmetry in criminal appeals was retained. Perhaps this is, in any event, the right way forward but alternatives were undiscussable and only those criminal matters which are raised as "devolution matters" will reach the Supreme Court when it absorbs the current jurisdiction of the JCPC. Similarly the rules on access to the court remain on an asymmetric basis which leaves Scotland with access as of right once the case is certified - a situation which gave rise to some embarrassment because of the risk of abuse in Wilson $V$ Jaymarke Estates Ltd 2007 SC(HL) 135.

What was quite apparent at the time of the debates on the Constitutional Reform Bill was that there were, within Scotland and in ways that did not simply divide Nationalists and Unionists, quite different perceptions of what purposes a UK Supreme Court might serve. Broadly there was a division between those who see the House of Lords and Supreme Court as providing a service to the Scottish legal system and those who see it as having an explicit UKwide responsibility to resolve the biggest legal questions in the state as a whole.

Perhaps of more continuing significance in a devolutionary context is my second Supreme Court point which focuses on the competence of the Scottish Parliament. Ever since the Scotland Act was passed there has been speculation about whether the Parliament could itself competently abolish appeals from Scotland to the House of Lords.

But then, in 2004, in the course of a debate on the Sewel Motion on the Constitutional Reform Bill it was reconfirmed that it was the policy of the SNP to repatriate Scottish appeals and to abolish appeals to the House of Lords or UK Supreme Court.

The issue was given a more concrete form when, in 2006, a Bill - a Member's Bill promoted by Adam Ingram MSP - was introduced which would have abolished House of Lords appeals but, at the same time, established a new Civil Appeals Committee in Scotland. However, that Bill quickly ran into difficulties. The Presiding Officer of the Parliament issued his statement on legislative competence and declared several provisions of the Bill to be beyond competence on the grounds of encroachment on the reserved matter of the Constitution and incompatibility with Convention rights. There has been criticism of the lack of any requirement in the Scotland Act that the content of the legal advice to the Presiding Officer be published but, in any event, in this case, the consequence of the statement was that the Parliament took advantage of procedures available under its Standing Orders to prevent further progress on the Bill. The indignant opposition of Adam Ingram - including attempts on his part to call in aid supportive views known to have been expressed by tutors in the Law School at the University of Edinburgh - was overridden by the then coalition government's parliamentary majority.

Since May 2007, of course, that is a position which has changed. Adam Ingram is now a minister in the SNP Scottish Government. That government does not have an overall majority in the Parliament but it might well be that support from other parties would be forthcoming. Another Civil Appeals Bill may be some way away yet but it seems likely, on the record of events so far, that initial steps in the direction of a new Bill may not be far away. (A few days after this lecture was delivered it was announced on December 15, 2008 by the Scottish Government that a research project led by Professor Neil Walker to review final civil appeals in Scotland was to be launched). The UK Supreme Court will go ahead in October 2009 but there may yet be, from the devolved Government of Scotland, a counter project in the making.

And, as I implied earlier, it might well be a counter project which would attract support, not just from other political parties but also from others who simply have a less centrist view of what top courts are supposed to do.

In conclusion, what are we to make of the developments I have so briefly surveyed? The devolution years have brought two different visions of future development. I make no personal judgment here on the pros and cons of the political divide between those who would strengthen and those who would weaken the Union. For the time being, however, we have the Union and, just as the political 
conditions for the sustainability of the Union have to be worked out if it is to continue effectively and the barriers to a working Union have to be removed (currently the Calman Commission's project), so too we have to take account of the more specifically legal characteristics of devolution within the Union. And, as I have tried to show, there have been contributions at the hands of both legislatures and courts in the direction of sustainable coexistence but there are also some areas where developments have been much more fraught. The lack of an agreed vision of what devolution under the Union entails threatens progress. As a result, two principal projects at the UK level - the UK Bill of Rights project and the creation of the UK Supreme Court - face substantial challenge.

(In March 2009, the UK and Scottish Governments agreed on a strategy to amend the Scotland Act 1998 to insert a 12-month time limit on human rights claims. In the same month, the UK Government published its Green Paper Rights and responsibilities: developing our constitutional framework (Cm 7577)).

Chris Himsworth

Professor of Administrative Law, University of Edinburgh

\section{W G Hart Legal Workshop 2009}

Tuesday 23 June - Thursday 25 June, $09.30-17.00$

Law reform and financial markets: institutions and governance

Academic Directors

\section{KERN ALEXANDER}

Queen Mary, University of London

JOANNA BENJAMIN

London School of Economics

\section{EILIS FERRAN}

University of Cambridge

NIAMH MOLONEY

London School of Economics

The financial market crisis continues to unfold and has raised important questions about the rule of law and the scope and intensity of regulation in financial markets. The effective operation of financial markets requires clear legal rules firmly embedded in a principled framework of private and public-law governance. In recent years, the role of law in financial markets has evolved substantially and in many ways has reflected changes in other areas of economic and social life. Regulating competing rights and interests among financial institutions, consumers and the broader economy has created many challenges that have tested the resilience of the financial system. The conference will provide a for um for academics and policymakers to address these challenges by exchanging ideas and research on issues concerning the role of law in financial market governance and institutional development. The issues will be addressed from an international and comparative dimension, along with inter-disciplinary contributions from other social scientists, with a view to developing a better understanding of how to use legal rules and principles to build more efficient and stable financial markets.

Topics proposed to be addressed at the conference will include (but are not restricted to)

- Changing structure of financial markets, externalities and the rule of law

- The scope of financial market regulation and the risks of a sectoral approach

- $\quad$ Redesigning banking law to enhance crisis management

- Comparative company law and corporate governance

- Investor and policyholder protection and the role of regulation

- Private law aspects of financial policy reform

- International economic law, financial stability, and international soft law

- Alternative legal systems: Sharia law and Chinese law

- Institutional design of financial markets and regulation

- The effectiveness of regional and international harmonization

- The design of enforcement structures

Submission of papers: April 30 was set as the date by which potential paper presenters should submit either a draft of the paper or a detailed outline or abstract, with preference given to in draft form. The final version of the papers to be submitted at the conference will be due on May 30 (all queries to Belinda.Crothers@sas.ac.uk). Further information on the workshop and this year's programme can be obtained from the IALS website (www.ials.sas.ac.uk). 